\title{
The Relationship between Personal Hygiene and Helminthes Disease on Primary School Children in Terminal Disposal Waste Area
}

\author{
Evawany Aritonang ${ }^{1}$, Albiner Siagian ${ }^{2}$ \\ ${ }^{1}$ Dept of Public Health Nutrition University of Sumatera Utara, Indonesia \\ evawany@gmail.com \\ ${ }^{2}$ Dept of Public Health Nutrition University of Sumatera Utara, Indonesia \\ albiner_sgnegmail.com
}

\begin{abstract}
More than two billion people worldwide infected with the worm. Several studies in Indonesia found $15-50 \%$ helminthes prevalence. Personal hygiene is one factor to helminthes disease and people in disposal waste area is high risk to infected especially primary student due to more active contact to the land. This cross sectional study wants to analyze relationship between personal hygiene and helminthes in 52 primary students as sample. Primary data consist of personal hygiene and helminthes status. The result showed that $57.7 \%$ primary student have not eligible personal hygiene such as $\mathbf{2 1 . 2 \%}$ student rarely wash their hands before eating, $11.5 \%$ never use the footwear when outside the home, and $25 \%$ student have habits of contact with the ground. The helminthes prevalence in this study is $17.3 \%$. There is no significant relationship $(\mathbf{p}>0.05)$ between personal hygiene and helminthes status.
\end{abstract}

Keywords - personal hygiene, helminthes, primary student, terminal disposal, waste area

\section{INTRODUCTION}

Helminthes is incident to the entry of worm eggs and infect the human intestine. The process in which this worm eggs through the soil so that the worm infection is generally referred to as soil transmitted helminthes. Helminthes is one public health problem in Indonesia because of its prevalence is still high enough.

Indonesia basic health research revealed that the prevalence of worm infection in Indonesia was $28.12 \%$ [1]. This high prevalence of worm infection is also seen in several studies in Indonesia in the range $15-50 \%[2,3,4]$. It is estimated that more than two billion people worldwide infected with the worm, where 300 million people experience severe infections and deaths occur every year 150 thousand people as a result of intestinal worm infections [5].

The prevalence of worm infestation in the province of Sumatera Utara, more than $10 \%$ whiles for the city of Medan no worm infection prevalence data [6]. Clean and healthy life behavior in Indonesia is still very far from expectations such as hand washing with soap before eating, wash hands with soap after defecating, the cleanliness of nails, a habit of using footwear outside the home, never take worms medicine, and so forth.

Clean and healthy life behavior are also synonymous with personal hygiene is the practice of personal hygiene habits such as bathing, washing, and toilet, which must meet health standards. Likewise, the level of environmental sanitation is still not good because there are many who do not meet the standards such as the availability of latrines, clean water sources and availability, and the availability of soap in the toilet. The research of Siti Chadijah, et al stated that there is a relationship of environmental sanitation with the incidence of intestinal worms in children of primary school in Palu city with $31.6 \%$ prevalence of worm infection [2].

Despite the relatively high prevalence of worm infection in Indonesia, but prevention and eradication of helminthes infections has not done optimally. This can be caused due to the impact of worm infections are not seen directly, so less enough attention from the government, especially by parents.

Landfill is an area classified as area prone to the incidence of intestinal worms. This is due to the soil moist by watering even the amount of landfill waste, so it is very suitable for the breeding of worms that are very vulnerable to the worm infection in children living around landfill. One 
landfill in the province of Sumatera Utara is Terjun Landfill in Terjun Village Medan Marelan SubDistrict. Terjun landfill is a landfill that accommodates garbage from the 23 districts in the city of Medan. Event delivery of waste to landfill is very active from morning until midnight at 23:00 pm. Prevalence of helminthes disease on primary student in the area of the landfill is not yet known.

In other hand personal hygiene behavior in primary student around the landfill is unknown. This research want to analyze whether there is a relationship of personal hygiene with the incidence of worm infection on primary student around landfills.

\section{MATERIALS AND METHODS}

This research is descriptive analytic design with "cross sectional study". Research will be carried out within a period of six months, from July to November 2016, in Terjun Landfill in Medan Marelan Subdistrict of Sumatera Utara Province. The population is all primary student grades 5 and 6 in school around landfill. There are two schools: government school and private school MIN Darul Ulum School with 86 student. The sample is total population who meet the inclusion criteria such as not suffering from the disease and willing to be sampled by signing an informed consent (willingness as sample). From a population of 86 students who are willing to be sampled are 52 people so the sample size is 52 students.

\section{RESULTS}

\section{A. Personal Hygiene}

Personal hygiene of primary student in general is not good, it means personal hygiene measures mostly student are not in accordance with the requirements (conditions) health is $57.7 \%$ of student personal hygiene is poor category. Some aspect of personal hygiene shown in table I.

TABLE I

PERSONAL HYGIENE

\begin{tabular}{|l|c|c|}
\hline \multicolumn{1}{|c|}{ Personal Hygiene } & n & \% \\
\hline Qualify & 22 & 42.3 \\
\hline Not eligible & 30 & 57.7 \\
\hline Total & 52 & 100 \\
\hline
\end{tabular}

Based on table I, it is known that many student who personal hygiene behavior is not in accordance with supposedly as more than $50 \%$ of student do not always wash their hands before eating, do not always wear shoes outside the house, and did not always wash their hands with soap after defecating (defecate). In addition $38.5 \%$ of student rarely nails if long nails. Likewise, the habit of eating snacks known that $20-30 \%$ of primary school children always buy food and drinks were no packed properly both at school and in the home environment.

TABLE II

ASPECTS OF PERSONAL HYGIENE

\begin{tabular}{|l|c|c|c|c|c|c|}
\hline \multicolumn{1}{|c|}{$\begin{array}{c}\text { Personal } \\
\text { Hygiene }\end{array}$} & \multicolumn{2}{|c|}{ Always } & \multicolumn{2}{c|}{ Rarely } & \multicolumn{2}{c|}{ Never } \\
\cline { 2 - 7 } & $\mathrm{n}$ & $\%$ & $\mathrm{n}$ & $\%$ & $\mathrm{n}$ & $\%$ \\
\hline $\begin{array}{l}\text { Wash hands } \\
\text { before eating }\end{array}$ & 40 & 76.9 & 11 & 21.2 & 1 & 1.9 \\
\hline $\begin{array}{l}\text { Wash your } \\
\text { hands with soap } \\
\text { after defecating }\end{array}$ & 35 & 67.3 & 14 & 26.9 & 3 & 5.8 \\
\hline $\begin{array}{l}\text { Use of footwear } \\
\text { when at home }\end{array}$ & 11 & 21.2 & 4 & 7.7 & 37 & 71.2 \\
\hline $\begin{array}{l}\text { Use of footwear } \\
\text { when outside } \\
\text { the home }\end{array}$ & 37 & 71.2 & 9 & 17.3 & 6 & 11.5 \\
\hline $\begin{array}{l}\text { Use of footwear } \\
\text { during recess at } \\
\text { school }\end{array}$ & 30 & 57.7 & 15 & 28.8 & 7 & 13.5 \\
\hline $\begin{array}{l}\text { Nails trimmed } \\
\text { when the long } \\
\text { nails }\end{array}$ & 24 & 46.2 & 20 & 38.5 & 8 & 15.4 \\
\hline $\begin{array}{l}\text { Contact with the } \\
\text { ground }\end{array}$ & 13 & 25.0 & 27 & 51.9 & 12 & 23.1 \\
\hline $\begin{array}{l}\text { Buying food/ } \\
\text { drink that is } \\
\text { open, no cover } \\
\text { or wrapper in } \\
\text { the home }\end{array}$ & 11 & 21.2 & 10 & 19.2 & 31 & 59.6 \\
\hline
\end{tabular}

\section{B. Helminthes Status of Primary School Student}

There are nine student positive worming. The types of worms that detect are Ascaris lumbricoides and Trichuiuris trichiura. Among of student positive worming, only one student infected with two types of worms, while eight student others were positive only have one type of worm that is only Ascaris lumbricoides or Trichuiuris trichiura.

TABLE III

STATUS HELMINTHES ON PRIMARY SCHOOL STUDENT

\begin{tabular}{|l|c|c|}
\hline \multicolumn{1}{|c|}{ Worming } & n & \% \\
\hline Positive & 9 & 17.3 \\
\hline Negative & 43 & 82.7 \\
\hline Total & 52 & 100.0 \\
\hline
\end{tabular}




\section{Personal Hygiene relationship with Helminthes}

According to the table IV showed that personal hygiene of primary school student who qualify more $(86.4 \%)$ were negative rather than positive wormy $(13.6 \%)$. But the personal hygiene of primary school student who do not qualify was also higher $(80 \%)$ are negative rather than positive wormy $(20.0 \%)$. Analysis of personal hygiene relationship with wormy showed that there is no significant relationship ( $p>0.05)$.

TABLE IV

PERSONAL HygIENE RELATIONSHIP WITH HELMINTHES

\begin{tabular}{|l|c|c|c|c|c|c|c|}
\hline \multirow{3}{*}{$\begin{array}{l}\text { Personal } \\
\text { Hygiene }\end{array}$} & \multicolumn{4}{|c|}{ Worming } & \multicolumn{2}{c|}{ Total } & \multirow{2}{*}{ p } \\
\cline { 2 - 7 } & \multicolumn{2}{|c|}{ Positive } & \multicolumn{2}{c|}{ Negative } & \multicolumn{2}{|c|}{} \\
\cline { 2 - 7 } & $\mathrm{n}$ & $\%$ & $\mathrm{n}$ & $\%$ & $\mathrm{n}$ & $\%$ & \\
\hline Qualify & 3 & 13.6 & 19 & 86.4 & 22 & 100.0 & 0.8 \\
Not eligible & 6 & 20.0 & 24 & 80.0 & 30 & 100.0 & 2 \\
Total & 9 & 17.3 & 43 & 82.7 & 52 & 100.0 & \\
\hline
\end{tabular}

\section{DISCUSSION}

Analysis of personal hygiene relationship with wormy showed that there is no significant relationship ( $p>0.05$ ). This is evident from the results, in which the majority of student wash their hands before eating, wash hands with soap after defecating, footwear when outside the home, footwear during recess at school, cutting the nails if long nails, infrequent contact with the ground, never buy food and drinks with no cover or wrapper in the home and school environment.

Therefore, because of the actions of other personal hygiene majority of student are already showing good personal hygiene the student are not many who have wormy when associated with personal hygiene. With the majority of personal action hygiene always wash hands before eating and wash hands with soap after defecating then most likely there is no correlation with the incidence of intestinal worms in primary school student.

Based on the survey results revealed that personal hygiene of student who qualify more $(86.4 \%)$ were negative rather than positive wormy $(13.6 \%)$. But the personal hygiene of student who do not qualify was also higher $(80 \%)$ are negative rather than positive wormy (20.0\%). Analysis of the relationship showed no significant association of personal hygiene and wormy primary school children.

This is in contrast with the study which states there is a relationship use Personal Protective Equipment (PPE), nail hygiene, hand washing, clean water, latrine ownership and sewage with the incidence of worm disease in workers vegetable in Maharatu Village [7]. Helminthes infection on vegetable workers is majority Ascaris lumbricoides with category minor infections.

Another study found that worm infection is more prevalent in children who are barefoot and not washing hands before eating. Based on this, health education about wormy and hygienic behavior healthy is essential to prevent worm infestation [8]. The prevalence of intestinal worms are still high in the world from the past to the present, it is examined in an epidemiological wormy survey by the method of systematic review states that worm disease remains high in many epidemiological studies conducted in Southeast Asia since 1947 until today [9].

Another study found a prevalence of worm infection in $30.3 \%$ of elementary school children where more men than women by wormy infection [10]. In this study recommended the need for the availability of clean water and proper garbage disposal facilities. Besides this research also states that checks routinely worm disease in primary school children are necessary to prevent the impact of worm infection on primary school children.

In addition the study of Hildya Kusmi, et al found that worm disease in junior high school students was $38 \%$ with the largest worms are ascaris lumbricoides $33 \%$, the rest is a worm Trichuris trichiura and both ascaris and trichuris [11]. Despite the high prevalence of worm infection but not statistically no significant association between the presence of toilets, availability of clean water and waste disposal facilities as well as the type of floor house with the occurrence of intestinal worms in junior high school student.

Factors leading to high worm infection is poor personal hygiene habits such as washing hands before eating and after defecation, nail hygiene, snack in place of cleanliness is not maintained, defecating in latrine in which led to pollution of soil and the environment by feces that containing worm 
and the availability of clean water sources. Worms that classified soil transmitted helminthes (STH) are Ascaris lumbricoides, Ancylostoma doudenale, Necator americanus, Trichuris trichiura and Strongyloides stercoralis [12].

\section{CONCLUSION}

There is no significant relationship $(\mathrm{p}>0.05)$ with the status of personal hygiene and worm infestation.

\section{REFERENCES}

[1] Ministry of Health. "The basic health research. Agency for Health Research and Development", 2013

[2] Sitti Chadijah, Phetisya Pamela Frederika Sumolang, Ni Nyoman Veridiana. "Relationship of Knowledge, Behavior, and Environment Sanitation Helminthiases Score in Children with Primary School in the city of Palu". Media Research and Development Vol. 24 No. 1 Reviews, Mar 2014, 50-56, 2014

[3] Sirajuddin and Masni. Anemia in. "Genesis Elementary School Students". Journal of the National Public Health Vol. 9, No. 3, February 2015, 2015

[4] Kundaian F, Jootje M. L. Umboh, Billy J. Kepel. "Relationship Between Environmental Sanitation with worm infestation in Primary School Pupils in Rural Teling Minahasa District of Tombariri”. Thesis Faculty of Public Health, University of Sam Ratulangi, 2011

[5] WHO. 2008. Worldwide prevalence of anemia 1993 - 2005, WHO global database on anaemia. Geneva: WHO library cataloguing-inpublication data

[6] North Sumatra Provincial Health Office. "The Health Profile of North Sumatera", 2012
[7] Rafiqi Ulfa Ali, Zulkarnaini, Dedi Affandi. "Personal Hygiene and Environmental Sanitation with Helminthiases Prevalence (Soil Transmitted helminths) on Vegetable Farmers in Maharatu Village Marpoyan Damai Sub District Pekanbaru City". Environmental dynamics Indonesia, January 2016 Volume 3, No. 1, p 24-32. 2016

[8] Tilahun Alelign, Abraham Degarege, and Berhanu Erko. "SoilTransmitted Helminth Infections and Associated Risk Factors among Schoolchildren in Durbete Town, Northwestern Ethiopia". Hindawi Publishing Corporation Journal of Parasitology Research Volume 2015

[9] Julia C. Dunn, Hugo C. Turner, Aung Tun and Roy M. Anderson. "Epidemiological surveys of, and research on, soil-transmitted helminths in Southeast Asia: a systematic review". Parasites \& Vectors journal vol 9:31. 2016

[10] Kelechi Kenneth Odinaka, Emeka Charles Nwolisa, Francis Mbanefo, Alfreda Chinekwu Iheakaram, and Seline Okolo. "Prevalence and Pattern of Soil-Transmitted Helminthic Infection among Primary School Children in a Rural Community in Imo State, Nigeria. Hindawi” Publishing Corporation Journal of Tropical Medicine Volume 2015

[11] Hildya Kusmi, Nuzulia Irawati, Husnil Kadri. "Home Environment Sanitation relationship with Infection Ascariasis and trichuriasis on Primary Students in Padang City". Andalas Medical Journal. 2015; 4 (3). http://jurnal.fk.unand.ac.id

[12] Rawina Winita, Mulyati, Hendri Astuty. "Relationship between Personal Sanitation and Helminthiases on Primary Student in Government School No X in Central Jakarta". Medical Faculty Magazine in Indonesia Christian University Vol XXVIII No 2. 2012 